\title{
A case of serendipity*
}

\section{T. Forrester}

Received: 21 July 2006 / Accepted: 26 February 2007 / Published online: 18 December 2007

(C) Springer Science + Business Media B.V. 2007

\begin{abstract}
An account is given of how a sensitive bioassay system for measurement of the neurotransmitter acetylcholine serendipitously led to the identification of adenosine triphosphate (ATP) released in vitro from active skeletal muscle. Subsequent application of the identification procedures to exercising human muscle in vivo, cardiac muscle cells in vitro, and human erythrocytes exposed to hypoxia gave rise to the general concept of ATP as a molecule that could influence cell function from the extracellular direction. Mechanisms of ATP release from cells in terms of "trigger" events such as mechanical distortion of the membrane, depolarization of the membrane, and exposure to hypoxia are discussed. Potential therapeutic uses of extracellular ATP in cancer therapy, radiation therapy, and a possible influence upon aging are discussed. Possible roles (distant and local) of extracellular ATP released from muscle during whole body exercise are discussed.
\end{abstract}

Keywords ATP release from cells · Exercise hyperemia . Extracellular ATP. Hypoxia · Serendipity

\section{Introduction}

In 1961 Boyd and Eadie [5] developed a highly sensitive bioassay for acetylcholine using an in situ perfusion technique of frog heart. Based on the great sensitivity of

*Serendipity: the faculty of happening upon fortunate discoveries when not in search of them. A word coined by Horace Walpole (1754) in The Three Princes of Serendip.

T. Forrester $(\bowtie)$

Department of Pharmacological and Physiological Sciences,

St. Louis University Medical Center,

St. Louis, MO 63104, USA

e-mail: FORRESMT@SLU.EDU the frog heart to acetylcholine (Fig. 1) a project was suggested by B. Katz to I. A. Boyd; they thought it possible that the amounts of acetylcholine released from stimulated motor nerve endings in frog skeletal muscle could be directly measured. The skeletal muscle to be used was the frog sartorius, about which a lot was known regarding the distribution and population of the motor nerve terminals. At that time the association of miniature end-plate potentials (MEPPs) with the release of acetylcholine in packets ("quanta") together with the anatomical existence of synaptic vesicles at the motor nerve terminals was highly plausible. Any accurate measurement of acetylcholine release from motor nerve stimulation would provide valuable evidence for (or against) the association and the establishment of the "quantal" theory of neuromuscular transmission. In essence the experimental approach mimicked the classic experiment of Otto Loewi, where fluid perfusing a first frog heart was used to perfuse a second heart. When the vagus nerve supplying the first heart was stimulated cardiac arrest occurred, and shortly after this the second heart also stopped beating. Loewi termed the vagal inhibitory transmitter Vagusstoff. An isolated frog sartorius was to be stimulated via the motor nerve in a bathing solution and the solution then perfused through a frog heart. When a stimulated muscle solution was perfused a surprising stimulatory response was elicited, quite unlike the anticipated inhibitory effect of acetylcholine (Fig. 1). Clearly this response would preclude any accurate assay for acetylcholine (as well as any successful conclusion to a thesis project aimed at substantiating the quantal theory of neuromuscular transmission!).

It was evident that for successful measurement of acetylcholine, the identification of the interfering substance, and its removal from the solution, had to be achieved. At this stage the basic question became: what substance(s) 


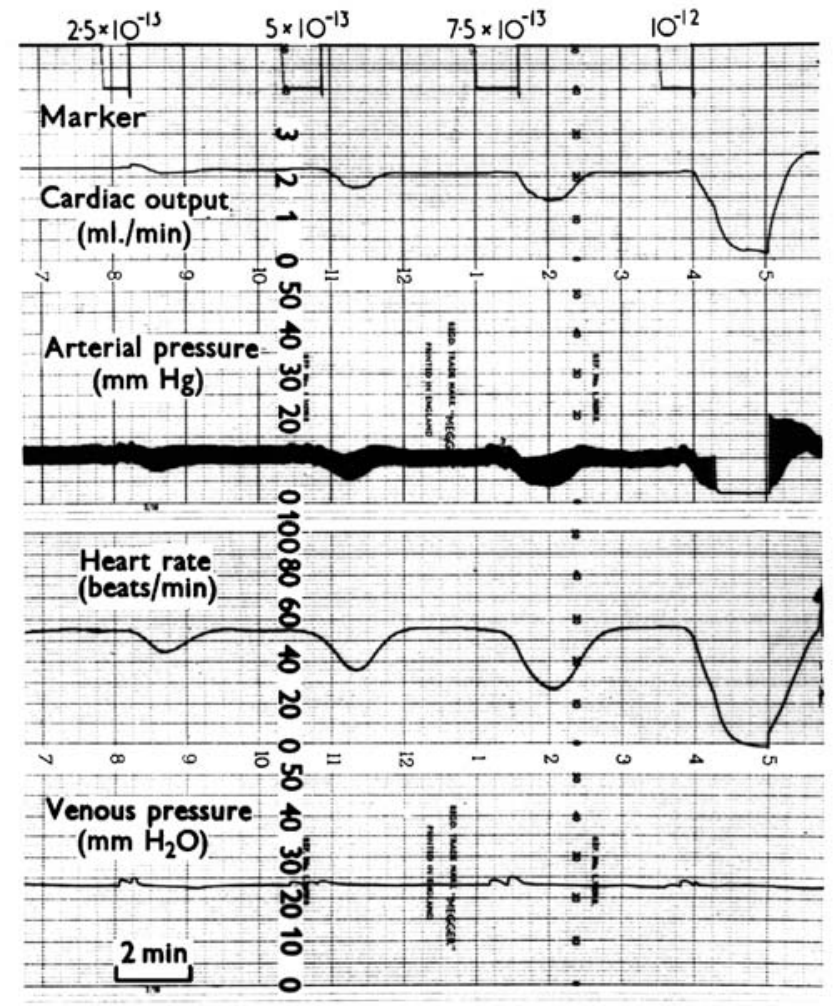

Fig. 1 The response of a very sensitive frog heart to graded concentrations of acetylcholine $\left(\mathrm{g} . \mathrm{ml}^{-1}\right)$. A concentration of $2.5 \times$ $10^{-13}$ g.ml ${ }^{-1}\left(1.54 \times 10^{-12} \mathrm{mmol} \cdot \mathrm{ml}^{-1}\right)$ produced a threshold response [19]

released from active skeletal muscle could possibly stimulate the frog heart? A "blunderbuss" approach was adopted, by perfusing through the heart as many available substances, known to exist in muscle, to see if any of them produced the stimulatory effect. The purine monophosphates and adenosine were eliminated since they did not stimulate the heart. Electrolyte changes, including an elevated potassium level, were also ruled out. Changes in calcium levels were hardly detectable in the bathing solution.

One obvious candidate as a stimulatory substance was catecholamine material. However, when the frog heart response to adrenaline was blocked by an ergot/pronethalol perfusion, the stimulatory effect remained (Fig. 3).

Indirect versus direct muscle stimulation The distribution of motor end plates in the sartorius muscle (there are no end plate regions at the pelvic end of the frog sartorius) allowed muscle fibers to be stimulated directly, without involvement of the neuromuscular junction in the activation process. Solutions bathing muscles stimulated directly produced the same stimulatory effect as the solutions from muscles stimulated via the motor nerve (indirect stimulation). This indicated that it was highly unlikely that the stimulatory substance had as its major source the activated motor nerve terminal.

\section{Identification procedures}

Identification of the stimulatory substance was established using three procedures: gel filtration, enzyme action of apyrase, and firefly tail luminescence.

Gel filtration chromatography The use of a gel filtration chromatography technique (Sephadex G-25, fine grade) enabled removal of protein from the stimulated muscle solution, allowing spectral absorbance analysis. An absorbance peak obtained at $265 \lambda$ was the first hint that a purine compound was present in the solution. The gel filtration technique also established a molecular weight of the stimulatory substance close to that of ATP.

In the face of prevailing dogma that ATP could not cross cell membranes, perfusion with ATP was reluctantly performed. A stimulatory effect was obtained-the author
Fig. 2 Effect of graded concentrations of ATP (g.ml $\left.{ }^{-1}\right)$ perfused through a frog heart [6]. Note that low concentrations have a pure inotropic effect, while a triphasic response was produced by higher concentrations. Further analysis of this triphasic response has since been made [17]

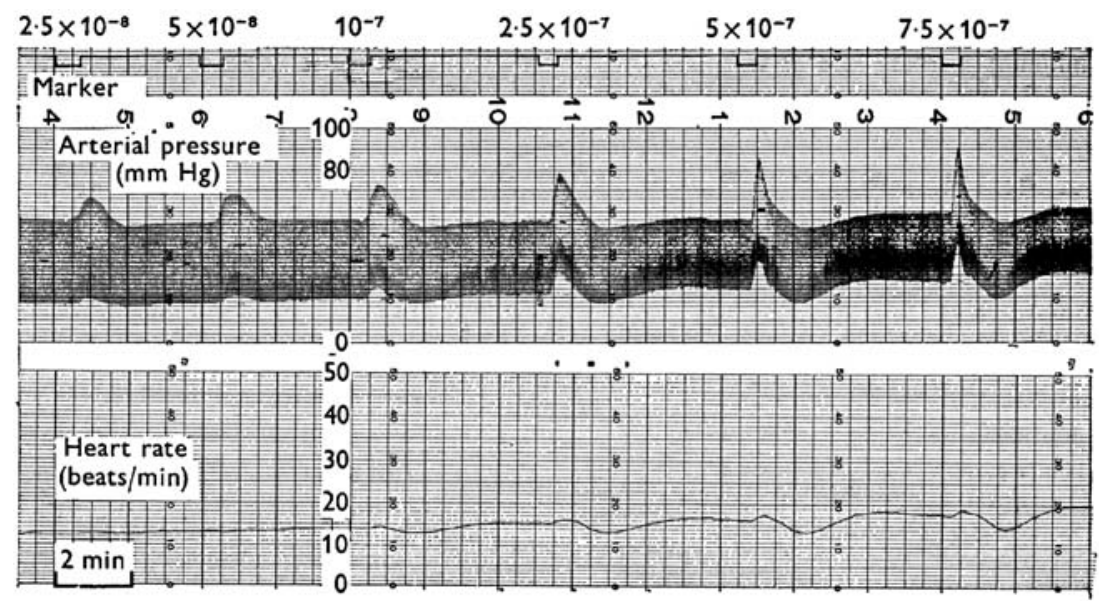




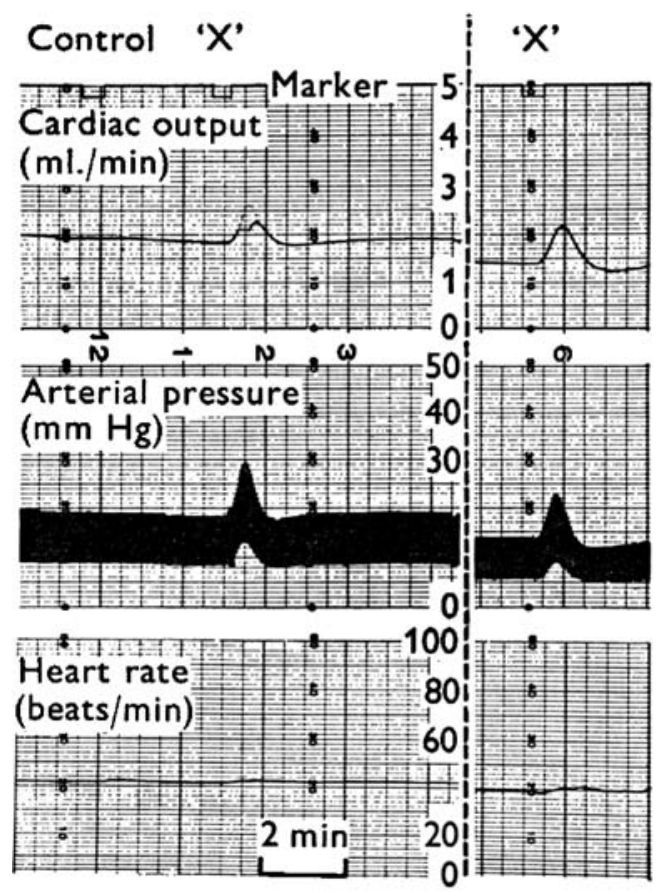

Fig. 3 Comparison of the stimulatory action of a stimulated muscle solution (' $\mathrm{X}$ ') on a frog heart before and after adrenergic blockade. Vertical interrupted line, 2-h period during which heart was perfused with pronethalol hydrochloride $\left(10^{-6} \mathrm{~g} \cdot \mathrm{ml}^{-1}\right)$ and ergotamine tartrate $\left(10^{-6}\right.$ g.ml $\left.l^{-1}\right)$. The stimulatory action of the stimulated muscle solution was unaffected by adrenergic blockade. Reproduced from Boyd and Forrester [6], with permission of the Physiological Society

had become a citizen of the Republic of Serendip! A dose response of the frog heart to ATP is shown in Fig. 2.

Incubation with apyrase In 1962 Traverso-Cori and Cori [61] demonstrated that an enzyme purified from potatoes ("apyrase") could selectively cleave the terminal phosphate of ATP. The stimulated muscle solution was incubated with apyrase, as were the stimulatory fractions from the gel filtration technique, and it was shown that the stimulatory effect was abolished, indicating that a phosphorylated compound was responsible for the stimulatory effect.

The luciferin/luciferase test for ATP As long ago as 1947 McElroy [38] showed that when a crude extract of lampyrid beetles (Photinus pyralis) was exposed to ATP a light signal was generated. When the stimulated muscle solution was applied to luciferin extract a light signal was produced (see [18]).

Procedures applied to perfused frog musculature

As this work developed the question "does ATP appear extracellularly as a result of tissue damage?" was frequently asked. Dissection damage to the sartorius muscle was avoided by the use of the perfused hindlimb preparation of the frog, where instrument trauma was limited to the insertion of cannulae. The identification procedures for ATP were applied to the perfusate from stimulated (indirect) hindlimb musculature. Table 1 shows the relationship of ATP output to the frequency of motor nerve impulses [23]. When these amounts $\left(0.24-1.8 \mathrm{nmol} 100 \mathrm{~g}^{-1}\right.$ $\mathrm{min}^{-1}$ ) are compared to the amounts of ATP released from isolated sartorius (50 $\mathrm{nmol} 100 \mathrm{~g}^{-1} \min ^{-1}$, [6]), it is seen that there is a great reduction detected in the perfusate sample, presumably as a result of exposure to greater ectoATPase activity that was not encountered in solutions bathing isolated muscles.

Procedures applied to human muscle in vivo

The appearance of ATP in the perfusate from active frog hindlimb musculature raised the possibility that ATP might be released from active muscle into the circulating blood in vivo. The identification procedures were applied to human plasma obtained from resting and exercising human forearm muscle [20, 21]. Figure 4 gives an example of the combined use of gel filtration chromatography, firefly luciferase, and apyrase for the identification and quantification of ATP in human plasma from exercising human forearm muscle [22]. Estimates of plasma ATP levels can only be approximate, since the accumulation in the blood is continuously offset by ATPase activity of both plasma and the surfaces of the erythrocyte and endothelial cells.

\section{Sequelae}

The present-day knowledge and extensive classification of purine receptors (see review by [48]) has vindicated the concept of an extracellular system of ATP action influencing many tissues of the body. However, the mode of ATP release from cells remains a formidable challenge (see review by [56]). In the cases of skeletal muscle, cardiac muscle, and erythrocyte some specific circumstances leading to ATP release, e.g. membrane depolarization, hypoxia, and mechanical distortion [25], should be addressed further.

Table 1 Relationship of ATP output to frequency of stimulation of perfused frog limb ${ }^{\mathrm{a}}$

\begin{tabular}{lll}
\hline $\mathrm{Hz}$ & pmol volley $^{-1} 100 \mathrm{~g}^{-1}$ & pmol $100 \mathrm{~g}^{-1} \mathrm{~min}^{-1}$ \\
\hline 1 & 4.0 & 240 \\
2 & 1.5 & 180 \\
5 & 1.4 & 420 \\
10 & 3.0 & 1,800 \\
\hline
\end{tabular}

${ }^{\mathrm{a}}$ Data from Forrester and Hassan [23] 


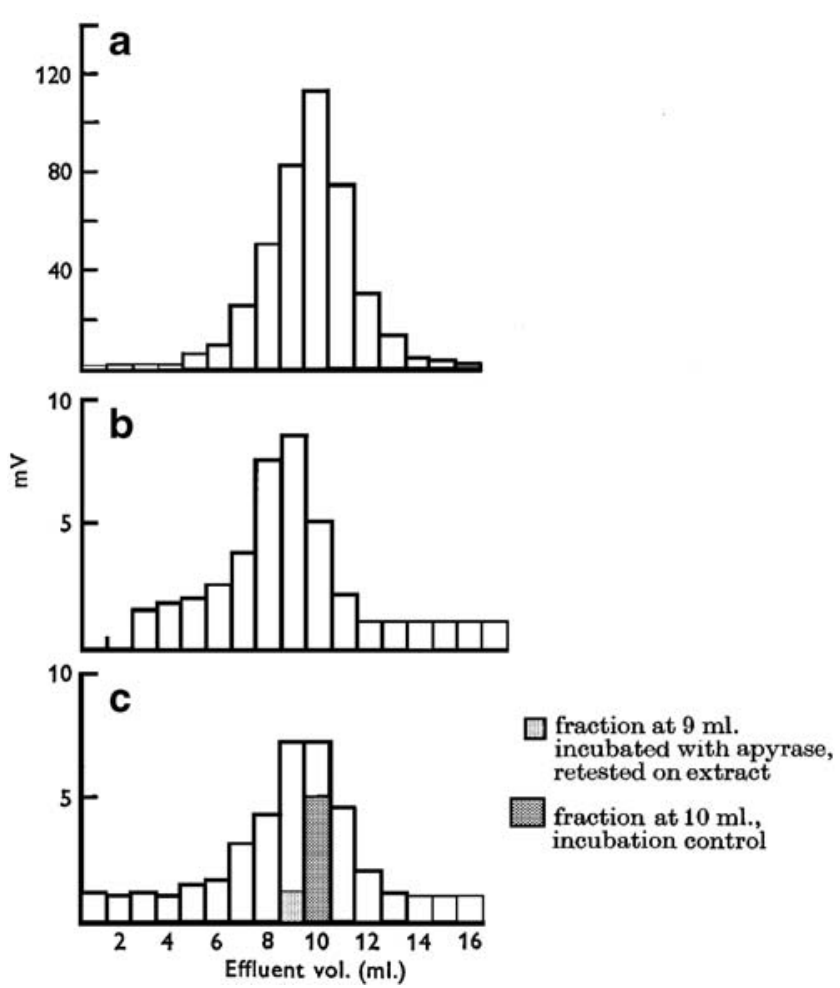

Fig. 4 Elution of ATP and plasma samples from exercising human forearm through a Sephadex column. Elution fractions were estimated with firefly extract. a ATP, $10^{-6}$ g. $\mathrm{ml}^{-1}$. b Post-occlusion human sample from a subject during forearm exercise. c Samples from another subject exercising forearm muscle, fraction at $9 \mathrm{ml}$ was incubated with apyrase and retested on firefly extract. Fraction at $10 \mathrm{ml}$, incubation control. Reproduced from Forrester [22], with permission of the Physiological Society

Association of ATP release from depolarizing membrane In 1962 Abood et al. [1] assessed outflux of various phosphates during membrane depolarization of excitable tissues. Prior to that Holton [32] detected ATP release from sensory nerves stimulated antidromically. An elegant experiment by Israel et al. [33] showed discrete release of ATP closely related to membrane depolarization in the electric organ of Torpedo. In 1973 Ohta et al. [40] studied and compared the mode of action of several veratrum alkaloid compounds on axonal membranes (squid giant axon). Some of them exerted a highly specific action on the resting sodium permeability, with veratridine having the most potent effect. Two results led them to conclude that the depolarization evoked by veratridine was caused by specifically increasing the membrane permeability to sodium ions: (1) application of tetrodotoxin (TTX), which specifically blocks sodium channels, restored the resting membrane potential after depolarization by veratridine and (2) removal of sodium ions from both external and internal phases of the axon, thus eliminating the sodium term from the GoldmanHodgkin-Katz constant field equation describing the membrane potential [31], had the result that veratridine had no depolarizing action after sodium removal. In 1977 White
[63] demonstrated ATP release from depolarizing isolated synaptosomes prepared from rat brain. The synaptosomes were suspended in a solution containing firefly extract. Depolarization was achieved by (1) elevation of extracellular potassium and (2) with application of veratridine. A light signal was evoked in both circumstances. Prior exposure of the synaptosomes to TTX, thus blocking the sodium channels, also blocked the light signal evoked by veratridine. This suggested that the release of ATP in response to veratridine in the absence of TTX was due to membrane depolarization following the opening of sodium channels. A record of one such experiment by Tom White is shown in a previous publication ([25] Fig. 16b).

Hypoxia The potency of hypoxia in evoking ATP release from heart cells and erythrocytes has been demonstrated [4, 24]. In the case of human erythrocyte, ATP release in response to hypoxia was very effectively blocked by the nucleoside transport blocker nitrobenzylthioinosine (NBTI). The nucleoside transporter has now been cloned [26] and is thought to be a member of a group of unclassified integral membrane proteins (see review by [8]). The connection between blockade of a nucleoside transporter and inhibition of nucleotide release (ATP) in response to hypoxia is unclear.

Some headway has been made toward unraveling oxygen-sensing mechanisms in certain oxygen-sensitive cells. In 1988 Lopez-Barneo et al. [36], studying chemoreceptive carotid body cells, demonstrated that lowered oxygen tension inhibited potassium channels, resulting in cell depolarization. The presence of oxygen-sensing potassium channels has been reported in many different cell types, for example, in pulmonary vascular myocytes, which constrict due to membrane depolarization following hypoxia [44] and in rat pheochromocytoma cells [12]. Does ATP release associated with membrane depolarization, as reported above [63], occur in these cells? Perhaps release of ATP from heart cells and erythrocytes in response to hypoxia involves the presence of oxygen-sensitive potassium channels, the sequence of events being hypoxia, leading to inhibition of oxygen-sensitive channels, followed by membrane depolarization and ATP release. To date, these potassium channels have not been identified in heart cells or erythrocytes.

Mechanical distortion A broad spectrum of mechanical distortion exists, ranging from gross distortion of whole cells to the impact of suction electrodes in the patch-clamp techniques for recording of currents passing through single ion channels in the membrane. There is little doubt that mechanical distortion of the whole cell membrane can lead to the release of ATP into the immediate environment. Sprague et al. [59] showed a close relationship between the 
extent of erythrocyte deformation and ATP release. Increases in shear stress applied to endothelial cells have been shown to liberate "vasoactive" substances from vascular endothelial cells [10, 45, 47, 54]. ATP release into the pulmonary vascular bed occurs within seconds after an increase in flow rate [30]. Grygoczyk and Hanrahan [27] clearly showed that minimum mechanical disturbance, such as changing the solution bathing the preparation, enhanced ATP release within seconds. Schwiebert [55] emphasized that the degree of suction pressure in patch-clamp techniques may determine the rate of ATP appearance. A further factor complicating physical distortion of the cell membrane is the possible involvement of the underlying cytoskeletal system. Frequency of membrane channel opening is influenced by exposure to cytochalasin B, which disrupts the cytoskeleton [62]. A comprehensive review by Morris [39] outlining the widespread occurrence of mechanosensitive ion channels in a variety of tissues is highly recommended.

\section{Perspectives}

Towards the search for an ATP channel in the plasma membrane Braunstein et al. [7], investigating the mechanism of cell volume regulation, showed that the cystic fibrosis transmembrane conductance regulator (CFTR) restored cell volume (following hypotonic challenge) by a mechanism involving ATP release. This release could be blocked by DIDS and gadolinium, suggesting that ATP might be released through a channel separate from the CFTR. Their working hypothesis was that cell volume is sensed and transduced by an ABC transporter (ATP binding cassette) enhancing ATP release through activation of a separate but associated ATP channel. The earlier observation [4] that hypoxic-induced ATP release from erythrocyte was associated with "band 3" membrane prompted the speculation that band 3 could be equated with the CFTR protein moiety. However, these proteins have been cloned and sequenced and are quite dissimilar in character [34, 52].

ATP passage across the inner mitochondrial membrane has long been known. Thinnes et al. [60] have identified a voltage-dependent anion channel (VDAC, "porin") which acts as a conduit for newly synthesized ATP in and out of the mitochondrion. VDAC is present in a multitude of tissue types, including human skeletal muscle [51] (Table 1).

Exercise and circulating purines An early example of the appearance of purines in the circulating blood in response to graduated whole body exercise was obtained by Peter
Parkinson [43]. It is known that a large proportion of circulating ATP is degraded in passage through the lung [15], perhaps, along with widespread ecto-ATPase activity, minimizing the effect of widespread vasodilatation and offsetting unwanted hypotension and collapse during exercise! The products of purine degradation are probably distributed generally, especially to tissues that cannot synthesize the purine ring moiety (see "Discussion," [11]). This phenomenon could appropriately be included in the concept of "ATP expansion" proposed by Abraham et al.

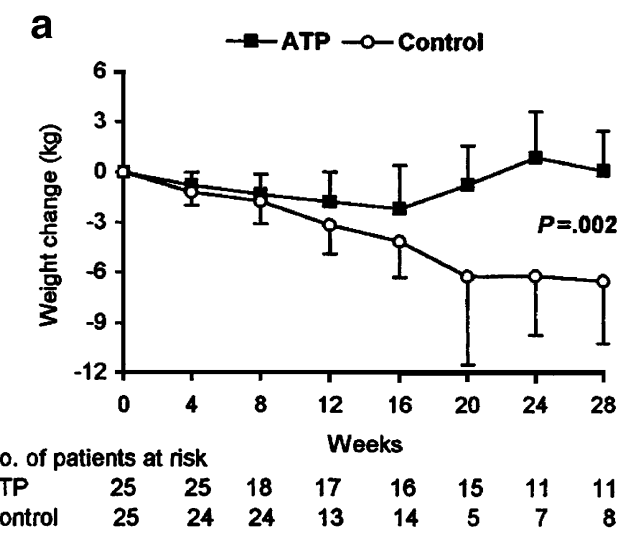

b
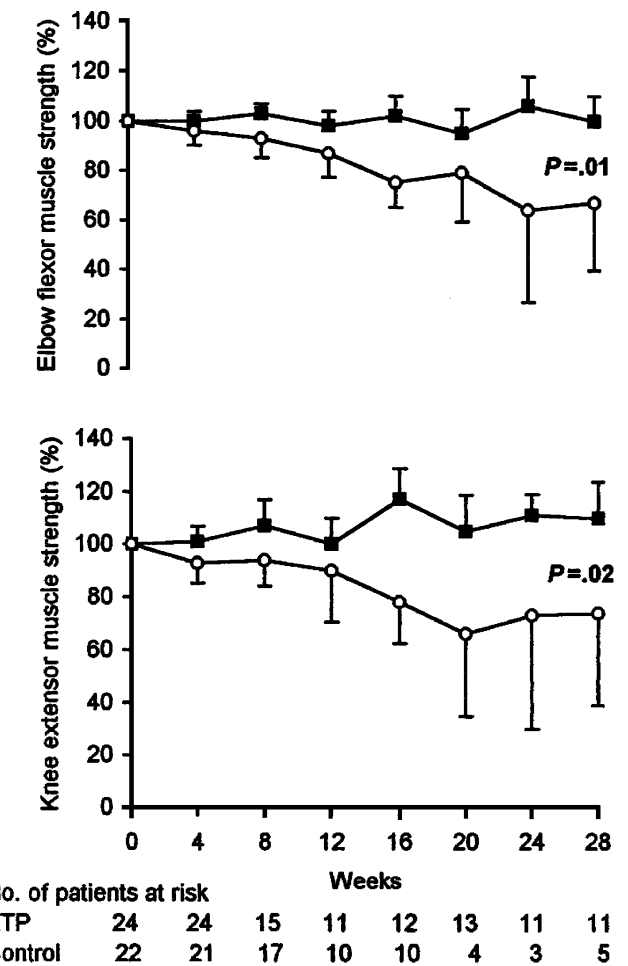

Fig. 5 Changes in body weight and muscle strength in advanced nonsmall-cell lung cancer after ATP administration. a Weight change. b Elbow flexor performance (top); knee extensor performance (bottom). Reproduced from Agteresch et al. [3], with permission 
[2]. This begs the question: is one of the beneficial effects of an exercise regime due to the intermittent "internal transfusion" of purines, including ATP, from exercising muscle to sustain "ATP expansion" in the tissues?

Use of ATP in cancer therapy Encouraging results have been obtained in the field of cancer therapy using extracellular ATP. A direct effect of ATP on tumor cells was demonstrated by Rapaport and coworkers [49, 50]. It was shown in various human cell lines that an increase in cellular ATP pools resulted in inhibition of DNA replication in the synthesis phase of the cell cycle, with subsequent arrest of cell growth. Inhibition of cancer growth in Ehrlich tumor cells by extracellular ATP has also been found [14, 35]. The dramatic weight loss seen in some forms of advanced cancer (cachexia) can be slowed with a regime of intravenous ATP [3]. As shown in Fig. 5 maintenance of muscle strength was also a benefit.

Protective effect of ATP against ischemia Improved recovery of ischemic liver, kidney, and myocardial tissues after perfusion of ATP-MgCl has been shown [9, 37, 41, 58].

Protective effect of ATP in radiation therapy Impairment of wound healing following radiation therapy has been shown to be ameliorated with use of ATP- $\mathrm{MgCl}$ perfusion regimes [57].

Although little understood, these protective effects may be associated with general elevation of tissue ATP levels, restoring the total "energy pool" of the body (see "ATP expansion" in review by [2]).

Aging and extracellular ATP levels The release of ATP from vascular endothelial cells in rat caudal artery is reduced with advancing age. Both spontaneous ATP release and release induced by methoxamine, an $\alpha$-adrenoceptor agonist, were reduced in aged vascular endothelium [28]. It is interesting that enhanced release of adenyl purines from these cells was invoked by hypotension induced by exercise [29]. A clear example of the effect of age on the ATP content of human erythrocytes is shown in Table 1 [46].

Aging has also been shown to diminish phosphorus metabolites in left ventricular hypertrophy as measured by

${ }^{31} \mathrm{P}$ magnetic resonance spectroscopy [42].

If aging is associated with lower tissue levels of ATP, and applied exogenous ATP can replenish these levels ("ATP expansion" see above), could aging reversal be brought about by increasing the exogenous ATP levels? At this juncture it should be noted that extracellular ATP can act as a powerful trigger of programmed cell death (apoptosis) in endothelial cells [13, 53]. Perhaps the phenomenon of apoptosis is designed to prevent the Malthusian nightmare of universal immortality!

\section{Epilogos}

And so what began as a project for the assessment of quantal release of acetylcholine from motor nerve terminals ${ }^{1}$ resulted in the finding that ATP was released from active skeletal muscle, leading to the establishment of a significant role for ATP in the hyperemia of exercising skeletal and heart muscle, as well as an appreciation of the widespread effects of extracellular ATP.

Intrinsic to the concept of serendipity in science is the element of surprise, which, although conferring excitement to investigators, only reveals our frailty of prediction in scientific matters. Inspirata accident magis saepe quam quae speres-What you do not expect happens more frequently than what you do expect (Plautus).

\section{References}

1. Abood LG, Koketsu K, Miyamoto S (1962) Outflux of various phosphates during membrane depolarization of excitable tissues. Am J Physiol 202:469-474

2. Abraham EH, Salikhova AY, Rapaport E (2003) ATP in the treatment of advanced cancer. In: Schwiebert EM (ed) Current topics in membranes, vol 54. Academic, San Diego, pp 415-452

3. Agteresch HJ, Dagnelie PC, van der Gaast A, Stijnen T, Wilson JHP (2000) Randomized clinical trial of adenosine 5-triphosphate in patients with advanced non-small-cell lung cancer. J Natl Cancer Inst 92:321-328

4. Bergfeld GR, Forrester T (1992) Release of ATP from human erythrocytes in response to a brief period of hypoxia and hypercapnia. Cardiovasc Res 26:40-47

5. Boyd IA, Eadie WR (1961) Continuous electronic recording of the activity of the perfused frog heart. J Br Instn Radio Engrs 22:433-447

6. Boyd IA, Forrester T (1968) The release of adenosine triphosphate from frog skeletal muscle in vitro. J Physiol 199:115-135

7. Braunstein GM, Roman RM, Clancy JP, Kudlow BA, Taylor AL, Shylonsky VG, Jovov B, Jilling T, Ismailov II, Benos DJ, Schwiebert LM, Fitz JG, Schwiebert EM (2001) Cystic fibrosis transmembrane conductance regulator facilitates ATP release by stimulating a separate ATP release channel for autocrine control of cell volume regulation. J Biol Chem 276:6621-6630

8. Cass CE, Young JD, Baldwin SA (1998) Recent advances in the molecular biology of nucleoside transporters of mammalian cells. Biochem Cell Biol 76:761-770

9. Chaudry IH, Clemens MG, Ohkawa M et al (1982) Restoration of hepatocellular function and blood flow following hepatic ischemia with ATP-MgCl2. Adv Shock Res 8:177-186

10. Christie MT, Griffith TM, Lewis MJ (1989) Comparison of basal and agonist-stimulated release of endothelium-derived relaxing factor from different arteries. Br J Pharmacol 98:397-406

11. Clemens MG, Forrester T (1981) Appearance of adenosine triphosphate in the coronary sinus effluent from isolated working rat heart in response to hypoxia. J Physiol 312:143-158

\footnotetext{
${ }^{1}$ Ultimately the quantal assessment was achieved using rat hemidiaphragm and bioassay with isometric leech muscle [16].
} 
12. Conforti L, Millhorn DE (1997) Selective inhibition of a slowinactivating voltage-dependent $\mathrm{K}+$ channel in rat PC12 cells by hypoxia. J Physiol 502(Pt 2):293-305

13. Dawicki DD, Chatterjee D, Wyche J, Rounds S (1997) Extracellular ATP and adenosine cause apoptosis of pulmonary artery endothelial cells. Am J Physiol 273:L485-L494

14. Estrela JM, Obrador E, Navarro J, Lasso de la Vega M, Pellicer JA (1995) Elimination of Ehrlich tumour by ATP-induced growth inhibition, glutathione depletion and X-rays. Nat Med $1: 84-88$

15. Evans RG, Forrester T, Mueller HS (1977) Intravascular passage of adenosine triphosphate through lung of baboon. J Physiol 276:70P-71P

16. Fletcher P, Forrester $T$ (1975) The effect of curare on the release of acetylcholine from mammalian motor nerve terminals and an estimate of quantum content. J Physiol 251:131-144

17. Flitney FW, Singh J (1980) Inotropic responses of the frog ventricle to adenosine triphosphate and related changes in endogenous cyclic nucleotides. J Physiol 304:21-42

18. Forrester $\mathrm{T}$ (1966) Release of adenosine triphosphate from active skeletal muscle. J Physiol 186:107-109P

19. Forrester $T$ (1967) The identification and assay of acetylcholine and adenosine triphosphate released from active skeletal muscle. Ph.D, thesis, University of Glasgow, Scotland

20. Forrester T (1969) The identification of adenosine triphosphate in fresh human plasma. J Physiol 200:53P-54P

21. Forrester T, Lind AR (1969) Identification of adenosine triphosphate in human plasma and the concentration in the venous effluent of forearm muscles before, during and after sustained contractions. J Physiol 204:347-364

22. Forrester T (1972) An estimate of adenosine triphosphate release into the venous effluent from exercising human forearm muscle. $\mathrm{J}$ Physiol 224:611-628

23. Forrester T, Hassan MO (1973) Appearance of adenosine triphosphate in the perfusate from active frog skeletal muscle. $\mathrm{J}$ Physiol 232:86P-88P

24. Forrester T, Williams CA (1977) Release of adenosine triphosphate from isolated adult heart cells in response to hypoxia. $\mathrm{J}$ Physiol 269:371-390

25. Forrester $\mathrm{T}$ (2003) A purine signal for functional hyperemia in skeletal and cardiac muscle. In: Schwiebert EM (ed) Current topics in membranes, vol 54. Academic, San Diego, pp 269-305

26. Griffiths M, Beaumont M, Yao SYM, Sundaram M, Boumah CE, Davies A, Kwong FYP, Coe I, Cass CE, Young JD, Baldwin SA (1997) Cloning of a human nucleoside transporter implicated in the cellular uptake of adenosine and chemotherapeutic drugs. Nat Med 3:89-93

27. Grygoczyk R, Hanrahan JW (1997) CFTR-independent ATP release from epithelial cells triggered by mechanical stimuli. Am J Physiol 272:C1058-C1066

28. Hashimoto M, Shinozuka K, Bjur RA, Westfall DP, Hattori K, Masumura S (1995) The effects of age on the release of adenine nucleosides and nucleotides from rat caudal artery. J Physiol 489:841-848

29. Hashimoto M, Shinozuka K, Tanabe Y, Gamoh S, Hara T, Hossain MS, Kwon YM, Kunitomo M, Masumura S (1999) Hypotension induced by exercise is associated with enhanced release of adenine purines from aged rat artery. Am J Physiol 276: H970-H975

30. Hassessian H, Bodin P, Burnstock G (1993) Blockade by glibenclamide of the flow-evoked endothelial release of ATP that contributes to vasodilatation in the pulmonary vascular bed of the rat. Br J Pharmacol 109:466-472

31. Hodgkin AL, Katz B (1949) The effect of sodium ions on the electrical activity of the giant axon of the squid. J Physiol 108:3777
32. Holton $P$ (1959) The liberation of adenosine triphosphate on antidromic stimulation of sensory nerves. J Physiol 145:494-504

33. Israel M, Lesbats B, Meunier FM, Stinnakre J (1976) Postsynaptic release of adenosine triphosphate induced by single impulse transmitter action. Proc R Soc Lond B Biol Sci 193:461-468

34. Kopito RR, Lodish HF (1985) Primary structure and transmembrane orientation of the murine anion exchange protein. Nature 316:234-238

35. Lasso de la Vega MC, Terradez P, Obrador E, Navarro J, Pellicer JA, Estrela JM (1994) Inhibition of cancer growth and selective glutathione depletion in Ehrlich tumour cells in vivo by extracellular ATP. Biochem J 298:99-105

36. Lopez-Barneo J, Lopez-Lopez JR, Urena J, Gonzalez C (1988) Chemotransduction in the carotid body: $\mathrm{K}+$ current modulated by PO2 in type I chemoreceptor cells. Science 241:580-582

37. McDonogh PF, Laks H, Chaudry IH, Baue AE (1984) Improved myocardial recovery from ischemia. Treatment with low-dose adenosine triphosphate-magnesium chloride. Arch Surg 119:1379-1384

38. McElroy WD (1947) The energy source for bioluminescence in an isolated system. Proc Natl Acad Sci U S A 33:342-345

39. Morris CE (1990) Mechanosensitive ion channels. J Membr Biol 113:93-107

40. Ohta M, Narahashi T, Keeler RF (1973) Effects of veratrum alkaloids on membrane potential and conductance of squid and crayfish giant axons. J Pharmacol Exp Ther 184:143-154

41. Ohkawa M, Clemens MG, Chaudry IH (1983) Studies on the mechanism of beneficial effects of ATP-MgCl2 following hepatic ischemia. Am J Physiol 244:R695-R702

42. Okada M, Mitsunami K, Inubushi T, Kinoshita M (1998) Influence of ageing on left ventricular hypertrophy of the human heart: content of phosphorus metabolites measured by 31P MRS. Magn Reson Med 39:772-782

43. Parkinson PI (1973) The effect of graduated exercise on the concentration of adenine nucleotides in plasma. J Physiol 234:72P-74P

44. Peers C (1997) Oxygen-sensitive ion channels. Trends Pharmacol Sci 18(11):405-408

45. Pohl U, Busse R, Kuon E, Basseny E (1986) Pulsatile perfusion stimulates the release of endothelial autocoids. J Appl Cardiol $1: 215-235$

46. Rabini RA, Petruzzi E, Staffolani R, Tesei M, Fumelli P, Pazzagli M, Mazzanti L (1997) Diabetes mellitus and subjects' ageing: a study on the ATP content and ATP-related enzyme activities in human erythrocytes. Eur J Clin Invest 27:327-332

47. Ralevic V, Lincoln, J, Burnstock G (1992) Release of vasoactive substances from endothelial. In: Ryan US, Rubanyi GM (eds) Endothelial regulation of vascular tone. Marcell Dekker, New York, pp 297-328

48. Ralevic V, Burnstock G (1998) Receptors for purines and pyrimidines. Pharmacol Rev 50:413-492

49. Rapaport E (1983) Treatment of human tumor cells with ADP or ATP yields arrest of growth in the S phase of the cell cycle. J Cell Physiol 114:279-283

50. Rapaport E, Fishman RF, Gercel C (1983) Growth inhibition of human tumor cells in soft-agar cultures by treatment with low levels of adenosine 5-triphosphate. Cancer Res 43:4402-4406

51. Reymann S, Florke H, Heiden M, Jakob C, Stadtmuller U, Steinacker P, Lalk EL, Pardowitz I, Thinnes FP (1995) Further evidence for multitopological localization of mammalian porin (VDAC) in the plasmalemma forming part of a chloride channel complex affected in cystic fibrosis and encephalomyopathy. Biochem Mol Med 54:75-87

52. Riordan JR, Rommens JM, Kerem B-S, Alon M, Rozmahel R, Grzelezak Z, Zielenski J, Lok S, Plavsic N, Chou J-L, Drumm ML, Iannuzzi MC, Collins FS, Tsui L-C (1989) Identification of 
the cystic fibrosis gene: cloning and characterization of complimentary DNA. Science 245:1066-1073

53. Rounds S, Yee WL, Dawicki DD, Harrington E, Parks N, Cutaia MV (1998) Mechanism of extracellular ATP- and adenosineinduced apoptosis of cultured pulmonary artery endothelial cells. Am J Physiol 275:L379-L388

54. Rubanyi GM, Romero JC, Vanhoutte PM (1986) Flow-induced release of endothelium-derived relaxing factor. Am J Physiol 250: H1145-H1149

55. Schwiebert EM (1999) ABC transporter-facilitated ATP conductive transporter. Am J Physiol 276:C1-C8

56. Schwiebert EM, Zsembery A, Geibel JP (2003) Cellular mechanisms and physiology of nucleotide and nucleoside release from cells: current knowledge, novel assays to detect purinergic agonists, and future directions. In: Schwiebert EM (ed) Current topics in membranes, vol 54. Academic, San Diego, pp 31-58

57. Senagore AJ, Milsom JW, Walshaw RK, Mostoskey U, Dunstan R, Chaudry IH (1992) Adenosine triphosphate-magnesium chloride in radiation injury. Surgery 112:933-939

58. Siegel NJ, Glazium WB, Chaudry IH, Gaudio KM, Lytton B, Baue AE, Kashgarian M (1980) Enhanced recovery from acute renal failure by the postischemic infusion of adenine nucleotides and magnesium chloride in rats. Kidney Int 17:338-349

59. Sprague RS, Ellsworth ML, Stevenson AH, Lonigro AJ (1996) ATP: the red blood cell link to NO and local control of the pulmonary circulation. Am J Physiol 271:H2717-H2722

60. Thinnes FP, Babel D, Heiden M, Hein A, Jurgens L, Konig U, Hilschmann N (1995) "Porin $31 \mathrm{HL}$ " in the plasmalemma of human cells: a VDAC discussed as part of a chloride channel complex in normal and cystic fibrosis B-lymphocyte cell lines. NATO ASI Series H: Cell Biology, vol 83. Springer, Berlin, pp 389-408

61. Traverso-Cori A, Cori O (1962) Splitting of the terminal phosphate group of adenosine triphosphate by potato apyrase. Biochim Biophys Acta 57:158-160

62. Weber K, Osborn M (1981) Microtubule and intermediate filament networks in cells viewed by immunofluorescence microscopy. In: Poste G, Nicolson GL (eds) Cytoskeletal elements and plasma membrane organization. Elsevier/North Holland Biomedical, Amsterdam, pp 1-55

63. White TD (1977) Direct detection of depolarization-induced release of ATP from a synaptosomal preparation. Nature 267: $67-68$ 